\title{
Audit quality, audit committee, media exposure, and Corporate Social Responsibility
}

\author{
Rawi $^{1}$, Munawar Muchlish ${ }^{2}$ \\ ${ }^{1}$ Department of Accounting, Swadaya Gunung Jati University, Cirebon, Indonesia \\ ${ }^{2}$ Department of Accounting, Sultan Ageng Tirtayasa University, Banten, Indonesia \\ *Corresponding author: r4wi.crb@gmail.com
}

\section{Article Info}

Article history:

Received : 31 March 2021

Accepted: 6 September 2021

Published: 1 January 2022

JEL Classification Code: M14, Q54

Author's email:

muchlish_ak@untirta.ac.id

DOI: $10.20885 /$ isb.vol26.iss1.art6

\begin{abstract}
Purpose: The specific purpose of this research can be developed more specifically to identify the influence of audit quality, audit committee, and media exposure on Corporate Social Responsibility. Corporate Social Responsibility is a social responsibility that is beneficial for the company itself, the local community as well as the community in general. Corporate Social Responsibility is basically a form of obligation and commitment of the company to pay attention to the interests of stakeholders for the sake of sustainable economic development in improving the quality of life.
\end{abstract}

Design/methodology/approach: This research used secondary data in the form of annual report of basic and chemical industry manufacturing companies listed on the Indonesia Stock Exchange from 2015 to 2019, with data sources accessed from www.idx.co.id. The sample withdrawal in this research used Purposive Sampling method which is a technique of determining samples with certain considerations, samples used as many as 120 samples. The analysis method used multiple linear analysis and t-test hypothesis.

Findings: The results showed that Audit Quality, Audit Committee, and Media Exposure had a partial positive effect on Corporate Social Responsibility. CSR is a form of commitment to business activities to act ethically, contribute to economic development, and improve the quality of life of workers and communities.

Research limitations/implications: The implications of research results, the higher the audit quality, the larger the number of audit committees and the higher the intensity of using the website in media exposure at the company, the greater the company in CSR disclosure.

Practical implications: Practical implications for investors, that the integrity of financial statements can be trusted by investors as investment decision making, while for companies/management, will get a positive value from the public regarding broad CSR disclosures.

Originality/value: This research is different from the previous research on the object of research and the most recent observation throughout the year. Thus, it can add the latest CSR research references by the development of CSR.

Keywords: Corporate Social Responsibility, audit quality, audit committee, media exposure

\section{Introduction}

The development of CSR (Corporate Social Responsibility) concept of the government has established Law No. 40 of 2007 on Limited Liability Companies article 1 paragraph 3 as follows; 
Social and Environmental Responsibility is the company's commitment to participate in sustainable economic development to improve the quality of life and the environment that is beneficial, both for the company itself, local communities, and the community in general, while in article 74 paragraph 1 the company that carries out its business activities in the field and/or related to natural resources must carry out Social and Environmental Responsibility. Further in paragraph 3 the company that does not carry out its obligations as referred to in paragraph (1) shall be subject to sanctions in accordance with the provisions of the legislation.

The Government of Indonesia supports environmental sustainability by issuing such government policies. The goal through social responsibility (CSR) activities, also known as triple bottom line (economic, social, and environmental), is expected that the company will not only focus on financial problems but also pay attention to the social and environmental conditions. CSR disclosure is one of the efforts made by the company to be able to meet the interests of stakeholders and ensure the long-term sustainability of the company. In a seminal work, Jensen, \& Meckling (1976) suggested that a good disclosure policy reduces agency costs and mitigates information asymmetry between managers and shareholders.

Corporate Social Responsibility (CSR) disclosure requires good corporate governance to achieve its objectives to the maximum sto get support from the board of directors, audit committee, and the wider community for the company's operational activities. The CSR disclosure standard that developed in Indonesia is referring to the standards developed by GRI (Global Reporting Initiatives). The Indonesian Management Accountants Association (IAMI) refers to the standards developed by GRI in awarding the Indonesia Sustainability Report Award (ISRA) to companies that participate in making sustainability reports. The GRI (2013) standard was chosen because it focuses on the disclosure standards of various economic, environmental, and social performance of companies to improve the quality of financial reporting and utilization of sustainability reporting

Audited financial statements are a necessity for the company and the management of the company while the financial statements become very important because of the information contained therein. Such information must have a reliable quality as it can be useful for the decisionmaking process. In theory, the company's financial statements audited by the Big Four Public Accounting Firm (KAP) are more qualified than the financial statements audited by the non-big four KAP. The ethical perspective of CSR in the context of auditor choice showed that socially responsible firms exhibit their adherence to ethical and responsible business principles by demanding higher audit quality (i.e., choosing big $\mathrm{N}$ auditors) to ensure greater assurance of financial reporting (Du et al., 2020).

An audit committee that meets frequently with all its members gives a signal of continuous monitoring to the market, reducing the need for public information disclosure in annual reports (Barros et al., 2013). Policy makers and accounting professionals provide a useful basis for assessing and enhancing Audit committee characteristics being associated with such committee effectiveness which is important to improve corporate disclosure practices (Madi et al., 2014).

Larger firms are more likely to attract media attention and hence engage in more CSR activities. When media freedom is greater, communication function becomes very important in social responsibility management (El Ghoul et al., 2019; Nur \& Priantinah, 2012). Communication of social responsibility through media will improve the company's reputation in the eyes of the public. Disclosures made by the company through the media become more valuable for investors; thus, the company can show transparency. Media exposure is a facility to assist in providing information to the public from all aspects. This facility provides many advantages for those who use it well. Especially for organizations or companies that will become more effective in the process of communication, especially in social responsibility activities or disclosure of social responsibility through media.

Corporate Social Responsibility is basically a form of obligation and commitment of the company to pay attention to the interests of stakeholders for the sake of sustainable economic development in improving the quality of life. The company's demands for CSR disclosure have emerged with the fact that the company socially has a social obligation to the community. Disclosure can be made through various means, such as through annual reports, advertisements, 
focus groups, trade unions, booklets, and school education (Sari, 2012). One of the implementations of good corporate governance is by sustainability CSR Disclosure to meet the interests of internal parties and external parties of the company. Some variables are considered to affect CSR disclosure. The quality of audit, audit committee, and media exposure affect corporate social responsibility.

\section{Literature Review and Hypothesis}

Agency theory was introduced by Jensen, \& Meckling (1976). They stated that "We define an agency relationship as a contract underwhich one or more persons (the principal(s)) engage another person (the agent) to perform some service on their behalf which involves delegating some decision making authority to the agent". Jensen \& Meckling (1976) argued that agency relationships as one or more contracts (called principals) appoint one or more others (called agents) to act on behalf of the authorizer and give power in decision making. Management as an agent seeks to have advantages, one of which is earnings management with CSR costs. The cost incurred by management for CSR is one of the agency costs, namely bonding costs.

Hackston, \& Milne (1996) stated that corporate social responsibility is the process of communicating the social and environmental impacts of an organization's economic activities on specific interested groups and society as a whole. Information about the company's social and environmental (CSR) activities and performance must be presented in financial reports. The reason is that the financial report is a "media" for communicating information about the company's financial position and performance of revenue, financing, and profit and loss activities in a period to stakeholders. From the media of financial reports, stakeholders (investors, creditors, suppliers, customers, government, and society) can assess the strength, dependence, risk, prospects, and sustainability of a company before making a decision.

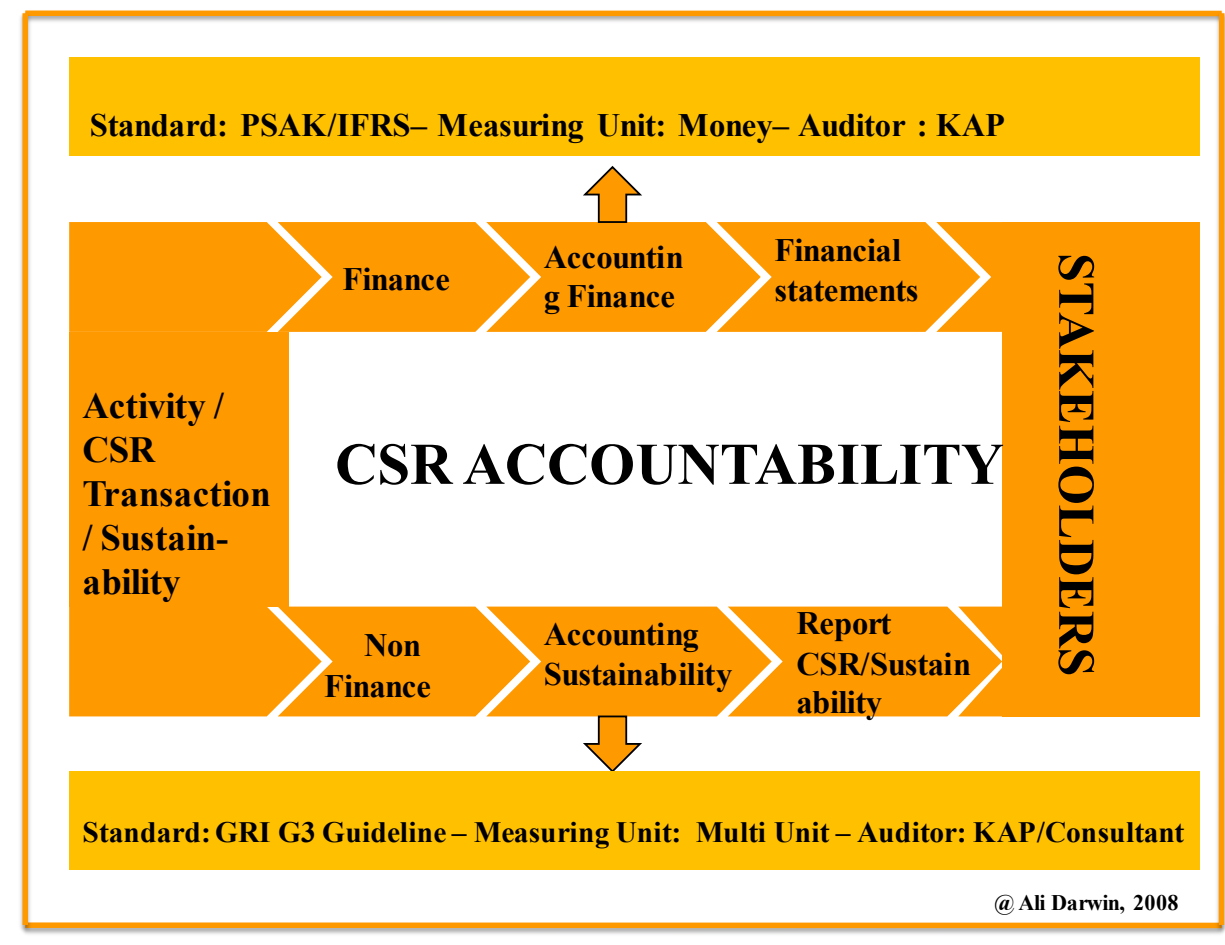

Source: Ali Darwin, 2008

Figure 1. Accountability for CSR

Deangelo (1981) defined audit quality as the probability where an auditor finds and reports about a violation in his audit accounting system. Audit quality is an important matter that must be considered by auditors in the auditing process. In conducting audits, auditors perform quality control to maintain audit quality. Quality control consists of the methods used to ensure that the 
company fulfills its professional responsibilities to stakeholders. Audit quality in the form of transparency requires accurate disclosure. One form of monitoring that can reduce agency costs is auditing. According to Tandiontong (2016), audit quality is all the probabilities of an auditor in determining and reporting fraud that occurs in the client's or company's accounting system.

One important design choice is to specify a reasonable period in which the changes in audit quality can be attributed to the auditor switch. A short period helps reduce the influence of confounding events, making it cleaner to measure the Big N effect. On the other hand, a short period assumes that a firm's audit quality changes immediately after hiring a Big N auditor, which could be unrealistic. Some prior research compares the audit quality between the last year of an outgoing auditor and the first year of an incoming auditor (Blouin et al., 2007)

The Indonesian Audit Committee Association (IKAI) (Effendi, 2016,p.48) expressed the understanding of the audit committee, namely: "A committee that works professionally and independently formed by the board of commissioners and, as such, its job is to assist and strengthen the functions of the board of commissioners (or supervisory board) in carrying out the supervisory functions of the financial reporting process, risk management, audit implementation, and implementation of corporate governance in companies. The Audit Committee has become a key element of auditors' communication with the parties responsible for governance. (Hery, 2017, p.24).

The audit committee is tasked with assisting commissioners in improving the quality of financial statements and improving the effectiveness of audits and external audits. Parties from outside the company are appointed as audit committee who have expertise and experience in accounting and or finance and have a good understanding of Corporate Governance. In its implementation and duties, the Audit Committee has the function of assisting the Board of Commissioners to; firstly, improving the quality of financial statements; secondly, creating a climate of discipline and control that can reduce the chance of irregularities in management within the company; thirdly, improving the effectiveness of internal audit functions (SPI) as well as external audits, as well as fourthly, identifying matters that require the attention of the Board of Commissioners/Board of Trustees.

Nur \& Priantinah (2012) stated that the future has it all: "the media is a resource on environmental information". Media Exposure or media's good name will be the process of communication through media or information through the media regarding social activities and other activity information. Misinformation is one of the possible ways that companies can get from the public or the parties that still exist. The presence of more intensive media exposure will increase the visibility of the company that will affect the public's view of things (Himel et al., 2016), while the existence of a good corporate governance framework affects the relationship between CEO media exposure and the more active use of CSR initiatives. In this sense, different factors that have been found to influence CSR issues might be taken into consideration, for example, ownership concentration (Díez et al., 2012)

There are two types of websites, namely static websites and dynamic websites. The definition of a static website is a website that informs one-way information, that is only derived from the owner of the software. Generally, this website is fixed, rarely changed, and can only be updated by the owner. Examples of these static websites are company profiles. While the dynamic website is a website that has a two-way flow of information, namely coming from users and owners; thus, updates can be done by users and also website owners. The type of website in this research was a static website (Dahlan, 2013).

\section{Hypotheses Development}

\section{Audit quality and corporate social responsibility}

Reports on various corporate activities, one of which includes the responsibility of the company must have a good audit quality and can be published or disclosed transparently. It will have a positive impact on the company's sustainability to develop and be sustainable. The disclosure of audit quality by the company, will build public trust and potential investors towards the company. Companies that have a high absolute level of discretionary accruals can indicate the existence of earnings management as well as show audit quality. In Agency theory, there is a bonding cost for 
audit fees, audit fees incurred for Big Four KAPs will be greater than those for non-Big Four KAPs, and the audit quality produced by Big Four KAPs will be better with Non-Big Four KAPs Good audit quality will reveal CSR more broadly and will increase the CSR rating. Previous research by Hapsoro, (2012); Gao \& Kling (2012); Ball et al. (2012); Barros et al. (2013); Iswandika et al. (2014); Pucheta-Martinez et al. (2018) \& Du et al. (2020) found that the quality of audits had a positive effect on CSR disclosures. Based on the results of previous research and audit quality, it can improve CSR rating. Thus, the hypothesis formulation is as follows:

H1: Audit quality has a positive effect on corporate social responsibility.

\section{Audit committee and corporate social responsibility}

The audit committee is an internal auditor formed by the Board of Commissioners, tasked with monitoring and evaluating the planning and implementation of the company's internal controls. The audit committee must be able to ensure that the company has implemented and complied with all applicable laws and regulations and ensures that the company carries out its business activities ethically and morally. Agency theory includes monitoring costs, costs incurred to monitor management behavior, and the audit committee that will always monitor management. The larger the audit committee, the better the company's internal control. Thus, CSR disclosure will also be wider and can increase the company's CSR rating. Research results of Badjuri (2011) and Melati (2014) stated that the audit committee affects the disclosure of Corporate Social Responsibility. Barako et al. (2006); Akhtaruddin \& Haron (2010); Barros et al. (2013); Othman et al. (2014); Madi et al. (2014); Nurfadilah \& Sagara (2016); Krisna \& Suhardianto (2016); Rochayatun (2016); Restu et al. (2017); Sheikh et al. (2019) and Putra \& Rivandi (2019) stated that the Audit Committee has a positive effect on the Disclosure Committee and can increase the CSR rating. The hypothesis is formulated as follows:

H2: The audit committee has a positive effect on corporate social responsibility.

\section{Media exposure and corporate social responsibility}

CSR communication through the media will improve the company's reputation in the eyes of the public. The Company wants to gain trust and legitimacy through CSR activities, so the company must have the capacity to meet the needs of stakeholders and communicate with its stakeholders effectively. Media Exposure is a means for companies to communicate their CSR activities on the company's website, where these activities can provide their own pluses in the eyes of the public. In agency theory there is a bonding cost, where the costs incurred are borne by management to be able to comply that management has behaved in the interests of the principal, one of which is the costs incurred for media exposure, the more often media exposure are made, the better, so that media exposure that are often done will be more widespread also in the disclosure of CSR. The results of research conducted by Reverte (2009); Zyglidopoulos et al. (2012; Kristi (2013); Saat \& Selamat (2014); Melati (2014); El Ghoul et al. (2019); Hao et al. (2018) and Godos-Díez et al. (2020) showed that media exposure influences CSR disclosures. Based on the results of previous research and media exposure that can improve CSR rating, the hypothesis formulation is as follows:

H3: Media exposure has a positive effect on corporate social responsibility.

\section{Research Method}

The population of this research was manufacturing companies in the basic and chemical sectors listed on the Indonesia Stock Exchange from 2015 to 2019. This research used secondary data in the form of annual report of basic and chemical industry manufacturing companies listed on the Indonesia Stock Exchange from 2015 to 2019, with data sources accessed from www.idx.co.id. Sample withdrawal in this research used Purposive Sampling method which was a technique of determining samples with certain considerations, samples used as many as 120 samples. 


\section{Operational Definition and Measurement of Variables}

Disclosure of social accountability information was data disclosed by companies related to social activities carried out by companies covering the themes of the environment, energy, health and safety of the workforce, other labor, products, public and general engagement (Reverte, 2009). CSR measurement is carried out by calculating the total CSR category items disclosed by the company. For each item disclosed is rated 1 and the undisclosed is rated 0 , this method is often called a data checklist. The total CSR disclosure according to GRI 4 is 91 items. CSR index measurement is done with the following formula:

$\mathrm{CSR}_{i}=\frac{\sum \mathrm{Xi}}{n i}$

Description:

CSR $i=$ Corporate Social Responsibility Index Company $i$

$\sum \mathrm{Xi}=$ Number of items disclosed by the company

$n i=$ Total items

GRI 04 consists of several categories, as follows:
1. Economic Category
9 Point
2. Environmental Category
34 Point

3. Social Category
a. Work Practice and Comfort work
16 Point
b. Human Rights
12 Point
c. Community
11 Point
d. Responsibility for the safety of products
9 Point
91Point Disclosure

Audit quality is measured using the category of the big four in Indonesia, namely: APB (Accounting Principle Board) Statement No. 4.

1. KAP Price Waterhouse Coopers (PWC), in collaboration with KAP Drs. Hadi Sutanto \& Partners, Haryanto Sahari \& Partners, KAP Tanudiredja, Wibisana, Rintis \& amp; Partners.

2. KAP Klynveld Peat Marwick Goerdeler (KPMG), in collaboration with KAP Sidharta-Sidharta \& amp;Widjaja.

3. KAP Ernest \& Young (E \& Y), in collaboration with KAP Prasetio, Sarwoko, \& amp; Sanjadja. KAP Purwantono, Suherman \& Surja

4. KAP Deloitte Touche Thomatsu (Deloitte), in collaboration with KAP Hans Tuanakotta \& Mustofa, Osman Ramli Satrio \& amp; Partners, Imelda \& amp; Partners.

The quality of auditors refers to whether the audited KAP belongs to the big four (dummy value 1) or non-big four (dummy value 0 ).

The audit committee size is measured by counting the members of the audit committee in the company. KAUD $=\Sigma$ member of the audit committee

Media exposure is done with dummy variables, namely by providing a value of 1 for companies that communicate CSR activities on the company's latest website and 0 for companies that do not disclose CSR activities on the company's latest website. Communication on the latest website 1; Communication is not on the latest website 0 .

The analysis in this research used Multiple Linear Regression Analysis with equations as follows:

$\mathbf{Y}=\alpha+\beta_{1} \mathbf{X}_{1}+\beta_{2} \mathbf{X}_{2}+\beta_{3} \mathbf{X}_{3}+\mathrm{e}$

Where:

$\mathrm{Y}=$ Corporate Social Responsibility

$\alpha=$ constant (fixed)

$\beta 1, \beta 2, \beta 3=$ regression coefficient

$\mathrm{X} 1$ = Audit Quality 
$\mathrm{X} 2$ = Audit Committee

$\mathrm{X} 3$ = Media Exposure

$\mathrm{e}=$ error

To produce a good model of regression equations, the assumption test is carried out first before analyzing using multiple linear regressions. The assumption tests to be performed are normality test, multicollinearity test, autocorrelation test, and heteroscedasticity test.

\section{Hypothesis Test}

This study using Test $t$, Statistical test $t$ basically shows how far the influence of one variable explanation/independent individually in explaining variations of dependent variables (Ghozali, 2018, p.98).

The zero (H0) hypothesis to be tested is a parameter $(\mu)$ equal to zero, or: $\mathrm{H} 0: \mu=0$

This means that an independent variable is not a significant explanation of dependent variables.

The alternate hypothesis (HA) parameter of a variable is not equal to 0 , or HA: $\mu \neq 0$

Test criteria:

a. Determine the level of significance $(\alpha)$, significance level used by $5 \%$

b. Decision making criteria; $\mathrm{H} 0$ is accepted and $\mathrm{HA}$ is rejected if $\mathrm{p}$-value $>5 \%$, HA received and $\mathrm{H} 0$ rejected if $\mathrm{p}$-value $\leq 5 \%$

\section{Result and Discussion}

\section{Descriptive Statistics}

Table 1. Descriptive Statistics

\begin{tabular}{lcccc}
\hline & $\mathrm{N}$ & Minimum & Maximum & Std. Deviation \\
\cline { 2 - 5 } & Statistic & Statistic & Statistic & Statistic \\
\hline CSR & 120 & .04 & .97 & .26268 \\
$\mathrm{AQ}$ & 120 & .00 & 1.00 & .50182 \\
$\mathrm{AC}$ & 120 & 2.00 & 4.00 & .31042 \\
$\mathrm{ME}$ & 120 & .00 & 1.00 & .43483 \\
Valid N (listwise) & 120 & & & \\
\hline
\end{tabular}

Source: Secondary data processed

The results of descriptive statistics showed that the lowest value for CSR variable was 0.04, Audit Quality variable was 0, Audit Committee variable was 2, and Media Exposure variable was 0, while for the highest value of each variable was CSR of 0.97, Audit Quality of 1, Audit Committee of 1 and Media Exposure of 1.

\section{Classic Assumption Test}

Table 2. Normality and Autocorrelation

\begin{tabular}{ccc}
\hline Variable & $\begin{array}{c}\text { One Sample KS } \\
\text { (sig. (2-tailed) }\end{array}$ & Durbin-Watson \\
\hline AQ, AC, ME & 0.363 & 1.966 \\
\hline
\end{tabular}

Source: Secondary data processed

Normality test is part of classic assumption test and it is a condition that to analyze using Regression analysis, assumption test must be performed. SPSS Output result for Normality test was based on Table 2. It concluded that normal distributed data with a value above sign value of $0.05 \%$ was 0.363 while for the autocorrelation test, this research used the tical test of Durbin Watson test. Based on Table 2, SPSS Output results showed the absence of autocorrelation symptoms in this research. 
Table 3. Multicollinearity and Heteroscedasticity

\begin{tabular}{|c|c|c|c|c|}
\hline \multirow{2}{*}{\multicolumn{2}{|c|}{ Variable }} & \multicolumn{2}{|c|}{ Collinearity Statistics } & \multirow[t]{2}{*}{ Sig } \\
\hline & & Tolerance & VIF & \\
\hline \multirow{4}{*}{1} & (Constant) & & & .051 \\
\hline & AQ & .923 & 1.083 & .894 \\
\hline & $\mathrm{AC}$ & 909 & 1.100 & .126 \\
\hline & ME & .958 & 1.044 & .151 \\
\hline
\end{tabular}

Source: Secondary data processed

The result of classic assumption testing of multicollinearity test can be seen in Table 3. It indicated that there was no multicollinearity problem. The value of all variables in this research had a VIF value of less than 10 and a Tolerance value of more than 0.01 while the heteroscedasticity test using Park test and SPSS Output showed no symptoms of heteroscedasticity that can be seen on all variables used from the sign value which was not significant above the value of 0.05 .

\section{Multiple Linear Regression Analysis Tests}

Table 4. Multiple Linear Regression

\begin{tabular}{lccc}
\hline \multicolumn{1}{c}{ Variable } & B & T & Sig \\
\hline (Constant) & -.781 & -2.994 & .003 \\
AQ & .117 & 2.670 & .009 \\
AC & .844 & 3.684 & .000 \\
ME & .211 & 4.229 & .000 \\
\hline Source: Secondary data processed & &
\end{tabular}

Source: Secondary data processed

\section{$\mathrm{CSR}=-0.781+0.117 \mathrm{AQ}+0.844 \mathrm{AC}+0.211 \mathrm{ME}+\mathrm{e}$}

Description:

CSR: Corporate Social Responsibility,

AQ : Audit Quality,

AC : Audit Committee,

ME : Media Exposure,

E : Error term

The equation of the regression model of Table 4 can be explained as follows: (a) The Regression Coefficient of Audit Quality had a positive value, meaning that if the Audit Quality improved then CSR increased. The regression coefficient value of 0.117 indicated that if the Audit Quality variable in basic industrial and chemical Companies increased by 1 unit, it would increase CSR by 0.117 units without being influenced by other factors; (b) The Coefficient of the Audit Committee had a positive value, meaning that if the Audit Committee improved then CSR increased. The coefficient value of 0.844 indicated that if the Audit Committee variable in The Basic and Chemical Industry Company increased by 1 unit, it would increase CSR by 0.844 without being influenced by other factors; (c) The regression coefficient of the Media Exposure variable had a positive value, meaning that if media exposure increased then CSR increased. The coefficient value of 0.211 indicated that if the media exposure variable in The Basic and Chemical Industry Company increased by 1 unit, it would increase CSR 0.211 without being influenced by other factors.

Table 5. Coefficient of Determination

\begin{tabular}{lcccc}
\multicolumn{4}{c}{ Model Summary $^{\mathbf{b}}$} \\
\hline Model & R Square & $\begin{array}{c}\text { Adjusted R } \\
\text { Square }\end{array}$ & $\begin{array}{c}\text { Std. Error of the } \\
\text { Estimate }\end{array}$ \\
\hline 1 & $.527^{\mathrm{a}}$ & .277 & .259 & .11899 \\
\hline a. Predictors: (Constant), ME, AQ, AC & \\
b. Dependent Variable: AbsUt &
\end{tabular}


Table 5 shows that the adjusted R Square value was 0.259 or $25.9 \%$, meaning that audit quality, Audit Committee and Media Exposure variables in explaining Corporate Social Responsibility were $25.9 \%$ while the remaining $74.1 \%$ was explained by other variables outside the regression model.

\section{Discussions}

The first hypothesis stated that Audit Quality has a positive effect on Corporate Social Responsibility. Based on the results of regression analysis in Table 4, the significance value of 0.009 had t calculate positive of 2.670. The results of this result showed that Audit Quality had a positive effect on Corporate Social Responsibility. This can be seen from the p-value result of $0.009<0.05$, the first hypothesis decision was accepted. The existence of good Audit Quality by reputable KAP and included in the KAP Big Four generated a wider the CSR disclosure. CSR is one form of fulfillment of expectations from stakeholders who will get more detailed information not only in the form of financial statements. The quality of audit is an important factor in maintaining the integrity of financial statements to be trusted by investors in investment decision making. Auditors from KAP Big Four are considered to be able to provide higher audit quality compared to auditors from KAP non-big four. The high quality of audits will affect corporate social responsibility disclosure. The Expenditure of audit fees for KAP by company management to comply with applicable company regulations, in agency theory audit fees are bonding costs. Company management will do their best for their company by using Big Four KAPs, which results in higher audit quality. Thus, it will support the company's CSR program. In line with the high audit quality, it will improve the CSR program and disclosure more broadly.

The second hypothesis stated that the Audit Committee had a positive effect on Corporate Social Responsibility. Based on the results of regression analysis in Table 4, significance value of 0.000 had a positive t count of 3.684. The results of this research showed that the Audit Committee had a positive effect on Corporate Social Responsibility. This can be seen from the p-value result of $0.000<0.05$, the second hypothesis decision was accepted. Corporate Social Responsibility (CSR) is a manifestation of the company's concern and sensitivity to help improve the quality of life of the community and the environment and is part of investment efforts that support the sustainability of developed businesses, inseparable from long-term strategic policies. The audit committee supervises the financial statements well in accordance with the applicable rules and he is honest. Thus, the audit committee with a large amount encouraged the management to perform environmental and social performance, not just report the finances.

The audit committee is a professional and independent working committee formed by an independent board of commissioners. Therefore, its task is to assist and strengthen the functions of the board of commissioners in carrying out the oversight function of the financial reporting process, risk management, audit implementation, and implementation of the corporate governance used (Tunggal, 2012). In theory, it is explained that the more the number of audit committees, the better the supervisory function provided; thus, social activities that run smoothly and legitimacy can be maintained (Krisna \& Suhardianto, 2016). Based on the theory of research results can be interpreted that the greater the number of audit committees in the company, the greater the company in disclosing CSR. The audit committee is an important tool in corporate governance in monitoring and internal control. In agency theory, there is a monitoring cost. The principal will monitor the behavior of the agent or company management, namely supervising, observing, and controlling the behavior of the agent. The audit committee supervises financial statements in accordance with applicable regulations. With more audit committee supervision, it may encourage the company's management to improve CSR programs as well as broader CSR disclosures.

The third hypothesis stated that Media Exposure has a positive effect on Corporate Social Responsibility. Based on the results of regression analysis in Table 4, the significance value was 0.000 with a positive t count of 4.229. The results of this research showed that Media Exposure had a positive effect on Corporate Social Responsibility. This can be seen from the p-value result of $0.000<0.05$, the third hypothesis decision was accepted. This indicated that the increasing level of media exposure with the media (website) will be more widespread on CSR coverage. CSR is a 
form of commitment to business activities to act ethically, contribute to economic development, and improve the quality of life of workers and communities. Media website as a place to provide information about the company's operations, CSR programs show the existence of effectiveness in its use. The website can be easily accessed by users, both the public, investors, the government, and other stakeholders. Thus, the company will get positive value from the public related to the media used by the company indirectly. The more high-intensity companies that use websites for media exposure, the more Corporate Social Responsibility disclosures. Agency theory has a bonding cost, where the company's management will incur costs for media exposure. The greater the cost of media exposure, the higher the media exposure will be. In media exposure there are CSR programs and disclosures, the higher the media exposure, the higher the CSR disclosure. Broader CSR Disclosure will improve the company's reputation. A good company reputation will have many benefits for both the internal parties of the company and the external parties of the company.

\section{Conclusion}

Based on the hypothetical test results, it can be concluded that The Audit Quality had a positive effect on Corporate Social Responsibility, auditors from KAP big four provided higher audit quality compared to auditors from KAP non-big four. The high quality of audits will affect Corporate Social Responsibility disclosure. Furthermore, the Audit Committee positively affects Corporate Social Responsibility, the more the number of audit committees it is expected to provide more CSR presentations. At last, Media Exposure had a positive effect on Corporate Social Responsibility. Indirectly, the company will get positive value from media exposure. The higher the intensity of the company using the website in media exposure, the more corporate the social responsibility disclosures presented.

\section{Implications}

\section{Theoretical implications}

The implications of the results of the research showed that the higher the quality of the audit, the number of audit committees and the high intensity of the use of websites in the media disclosure in the company, the greater the company in CSR disclosure. Good audit quality will reveal CSR more widely, while corporate governance carried out by applicable procedures will always be monitored by the audit committee so that the more audit committees and media disclosures that are always carried out, the management will improve the CSR program and its disclosure will be wider.

\section{Managerial implications}

The practical implications for investors are the integrity of financial statements that can be trusted by investors as investment decision making, getting positive value in the form of improving the company's image in the community and the public related to the broad disclosure of CSR. This improvement also potentially increasing employee commitment to the company, as well as maintaining good management relationships with stakeholders.

\section{References}

Akhtaruddin, M., \& Haron, H. (2010). Board ownership, audit committees' effectiveness, and corporate voluntary disclosures. Asian Review of Accounting, 18(3), 245-259.

Badjuri, A. (2011). Faktor-Faktor Fundamental, Mekanisme Corporate Social Responsibility (CSR) Perusahaan Manufaktur dan Sumber Daya Alam di Indonesia. Dinamika Kenangan Dan Perbankan, 3(1), 38-54.

Ball, R., Jayaraman, S., \& Shivakumar, L. (2012). Audited financial reporting and voluntary disclosure as complements: A test of the Confirmation Hypothesis. Journal of Accounting and 
Economics, 53(1-2), 136-166.

Barako, D. G., Hancock, P., \& Izan, H. Y. (2006). Corporate Disclosure by Kenyan Companies. Corporate Governance, 14(2), 107-125.

Barros, C. P., Boubaker, S., \& Hamrouni, A. (2013). Corporate governance and voluntary disclosure in France. Journal of Applied Business Research, 29(2), 561-578.

Blouin, J., Grein, B. M., \& Rountree, B. R. (2007). An analysis of forced auditor change: The case of former Arthur Andersen clients. Accounting Review, 82(3), 621-650.

Dahlan, M. (2013). Membuat Web PHP. Yogyakarta: Mitra Utama.

DeAngelo, L., ,E. (1981). Auditor Size and Auditor Quality. Journal of Accounting and Economics, 3(3), 183-199.

Díez, J. L., Gago, R. F., \& García, L. C. (2012). Propiedad y control en la puesta en práctica de la RSC. Cuadernos de Economía y Dirección de la Empresa, 15(1), 1-11.

Du, S., Xu, X., \& Yu, K. (2020). Does corporate social responsibility affect auditor-client contracting? Evidence from auditor selection and audit fees. Advances in Accounting, 51, 1-15.

Effendi, M., A. (2016). The Power of Good Corporate Governance Teori dan Emplementasi. Jakarta: Salemba Empat

El Ghoul, S., Guedhami, O., Nash, R., \& Patel, A. (2019). New Evidence on the Role of the Media in Corporate Social Responsibility. Journal of Business Ethics, 154(4), 1051-1079.

Gao, L., \& Kling, G. (2012). The impact of corporate governance and external audit on compliance to mandatory disclosure requirements in China. Journal of International Accounting, Auditing, and Taxation, 21(1), 17-31.

Ghozali, I. (2018). AplikasiAnalisis Multivariate dengan Program IBM SPSS 25. Semarang: Badan Penerbit Universitas Diponegoro

Godos-Díez, J. L., Cabeza-García, L., Fernández-Gago, R., \& Nieto-Antolín, M. (2020). Does CEO media exposure affect corporate social responsibility? Corporate Social Responsibility and Environmental Management, 27(2), 825-840.

GRI. (2013). G4 Sustainability Reporting guidelines: Global Reporting Initiative.

Hackston, D \& Milne, M., J. (1996). Some Determinants of Social and Environmental Disclosures in New Zealand Companies. Accounting, Auditing, \& AccountibilityJournal. 9(2), 77-108.

Hao, Y., Farooq, Q., \& Sun, Y. (2018). Development of theoretical framework and measures for the role of social media in realizing corporate social responsibility through native and nonnative communication modes: Moderating effects of cross-cultural management. Corporate Social Responsibility and Environmental Management, 25(4), 704-711.

Hapsoro, D. (2012). Pengaruh Corporate Governance dan Kualitas Audit Terhadap Pengungkapan Corporate Social Responsibility. Jurnal Akuntansi dan Manajemen. 23(3), 199-215

Hery. (2017). Kajian Riset Akuntansi. Jakarta: PT Grasindo

Himel, T. H., Muniandy, S. L., \& Rahman, A. A. (2016). The relationship between self-efficacy, feasibility, and awareness towards green entrepreneurial intention. Sci.Int. (Labore), 28(2), 2095-2103.

Iswandika, R., Murtanto, Sipayung, E. (2014). PengaruhKinerjaKeuangan,Corporate Governance, danKualitas Audit TerhadapPengungkapan Corporate Social Responsibility. e-Journal Akuntansi FE Trisakti. 1(2), 1-18

Jensen, M. C., \& Meckling, W. H. (1976). Theory of the firm: Managerial behavior, agency costs, and ownership structure. Journal of financial economics, 3(4), 305-360. 
Krisna, A. D., \& Suhardianto, N. (2016). Faktor-faktor yang mempengaruhi pengungkapan tanggung jawab sosial. Jurnal Akuntansi dan Keuangan, 18(2), 119-128.

Kristi, A. A. (2013). Faktor-Faktor Yang Mempengaruhi Pengungkapan Corporate Social Responsibility pada Perusahaan Publik Di Indonesia. Fakultas Ekonomi Dan Bisnis Universitas Brawijaya, 53(9), 1-27.

Madi, H. K., Ishak, Z., \& Manaf, N. A. A. (2014). The Impact of Audit Committee Characteristics on Corporate Voluntary Disclosure. Procedia - Social and Behavioral Sciences, 164(August), 486-492.

Pucheta-Martínez, M. C., Bel-Oms, I., \& Rodrigues, L. L. (2019). The engagement of auditors in the reporting of corporate social responsibility information. Corporate Social Responsibility and Environmental Management, 26(1), 46-56.

Melati, P. (2014). Faktor-faktor Yang Mempengaruhi Corporate Social Responsibility (CSR) Studi (Empiris Pada Perusahaan Industri Dasar Dan Kimia Yang Terdaftar Di BEI Periode 20102012). Jurnal Ekonomi Universitas MAritim Raja Ali Haji, 3(5), 35-54.

Nur, M., \& Priantinah, D. (2012). Analisis Faktor-Faktor Yang Mempengaruhi Pengungkapan Csr Diindonesia (Studi Empiris Pada Perusahaan Berkategori High Profile Yang Listing Di Bei). Jurnal Nominal, I(I), 1-13.

Nurfadilah, W., \& Sagara, Y. (2016). Pengaruh Good Corporate Governance, Karakteristik Perusahaan Dan Regulasi Pemerintah Terhadap Pengungkapan Corporate Social Responsibility. Akuntabilitas, 8(1), 78-89.

Othman, R., Ishak, I. F., Arif, S. M. M., \& Aris, N. A. (2014). Influence of Audit Committee Characteristics on Voluntary Ethics Disclosure. Procedia - Social and Behavioral Sciences, 145, 330-342.

Putra, A., H.\& Rivandi, M. (2019). Pengaruh Dewan Komisaris dan Komite Audit Terhadap Pengungkapan Corporate Social Responsibility. Academic Conference of Accounting. 1(1), 76-93

Restu, M., Yuliandari, W. S. \& Nurbaiti, A. (2017). Pengaruh Ukuran Dewan Komisaris, Proporsi Dewan Komisaris Independen dan Ukuran Komite Audit Terhadap Pengungkapan Corporate Social Responsibility (studi kasus pada perusahaan BUMN yang terdaftar di Bursa Efek Indonesia periode 2013- 2016). Jurnal Ekonomi Dan Bisnis. 4(3), 2742-2749

Reverte, C. (2009). Determinants of corporate social responsibility disclosure ratings by Spanish listed firms. Journal of Business Ethics, 88(2), 351-366.

Rochayatun, S. (2016). Faktor-faktor Yang Mempengaruhi Corporate Social Responsibility Disclosure (CSRD). Jurnal Penelitian Ilmu Ekonomi Wiga. 6(1), 63-79.

Saat, R. M., \& Selamat, M. H. (2014). An Examination of Consumer's Attitude towards Corporate Social Responsibility (CSR) Web Communication Using Media Richness Theory. Procedia Social and Behavioral Sciences, 155(October), 392-397.

Sari, R. A. (2012). Pengaruh karakteristik perusahaan terhadap corporate social responsibility disclosure pada perusahaan manufaktur yang terdaftar di bursa efek Indonesia. Nominal: Barometer Riset Akuntansi dan Manajemen, 1(2), 124-140.

Sheikh, R. A. G., Abdullah \& Shah, M. H. (2019). Impact of Audit Committee Characteristics on Voluntary Disclosures: Evidence from Pakistan. Asian Journal of Economics and Empirical Research, 6(2), 113-119.

Tandiontong, M. (2016). Kualitas Audit dan Pengukurannya. Bandung: Alfabeta

Tunggal, A., W. (2012). Audit Kecurangan dan Akuntansi Forensik. Jakarta: Harvarindo

Zyglidopoulos, S. C., Georgiadis, A. P., Carroll, C. E., \& Siegel, D. S. (2012). Does media attention drive corporate social responsibility? Journal of Business Research, 65(11), 1622-1627. 